\title{
Inovativne ili bogate regije? Prostorna ekonometrijska analiza regija Europske unije
}

\author{
Marko Grdešić \\ Doktorski student, Odsjek za sociologiju, Sveučilište u Wisconsinu, Madison, WI \\ e-mail:grdesic@wisc.edu
}

\begin{abstract}
SAŽETAK Ovaj se rad bavi prostornom ekonometrijskom analizom podataka o regijama Europske unije. Osnovni je cilj rada rasvijetliti čimbenike koji su povezani s ekonomskim uspjehom regija. Ekonomski se uspjeh definira na dva načina: kao opća razina ekonomskog bogatstva i kao uspjeh u znanstveno-tehnološkom inoviranju. Primjenjuju se metode vizualne i eksplorativne prostorne analize i multivarijantni modeli prostorne zavisnosti. Prostorno je grupiranje značajniji čimbenik kada je riječ o ekonomskom bogatstvu nego kada je riječ o uspjehu u znanstveno-tehnološkom inoviranju. Drugim riječima, regije mogu postati inovativne premda se ne nalaze u inovativnom okruženju, ali mnogo teže postaju bogate ako nisu u bogatom okruženju. Multivarijantna analiza otkriva kako su ova dva modela ekonomskog uspjeha povezana $s$ različitim nezavisnim varijablama. Za razliku od uspješnosti shvaćene kao bogatstvo, uspješnost shvaćena kao inovativni potencijal povezana je s faktorima koji upućuju na liberalniji i manje egalitarni oblik razvoja. Ova se razvojna dvojba posebno oštro postavlja pred postkomunističke regije u Istočnoj Europi.
\end{abstract}

Ključne riječi: prostorna analiza, prostorna zavisnost, Europska unija, NUTS-II, regije, regionalni razvoj, regionalna politika.

\section{Uvod}

Koji čimbenici vode uspješnom regionalnom razvoju? Ovaj rad pristupa tom pitanju uz tri početne motivacijske teze. Prvo, u europskom kontekstu analiza regionalnog razvoja mora biti utemeljena na analizi regija Europske unije. ${ }^{1}$ One su glavni nosioci lokalnog i regionalnog razvoja, kao i bogat izvor javno dostupnih podataka. Drugo, analiza uspješnosti regija zahtijeva prostornu i geografsku analizu koja uzima u obzir ne samo karakteristike promatrane regije nego i položaj regije u prostoru. S obzirom na visoku kvalitetu podataka Europske unije, prostorna analiza regionalne uspješnosti može biti operacionalizirana kroz ekonometrijsku analizu. Pri tome se mogu koristiti regresijski modeli koji obraćaju pažnju na lokaciju i međupovezanost regija u

$\mathbf{1}$ Kao regije EU u ovom se radu koriste statističke regije NUTS te posebice tzv. NUTS-II regije. U analizi se koriste podaci za 27 zemalja članica i Hrvatsku. 
prostoru. I treće, samu ekonomsku uspješnost regija može se definirati na nekoliko načina. U ovom se radu koriste dvije definicije: uspješnost u dostizanju opće razine ekonomskog bogatstva i uspješnost u znanstveno-tehnološkom inoviranju.

Osnovni su zaključci rada sljedeći. Prvo, prostorni se aspekt pokazao važnim: veća je vjerojatnost da je neka regija uspješna ukoliko je okružena drugim uspješnim regijama. Također vrijedi i obratno: i neuspješne se regije grupiraju zajedno. Međutim proces prostorne povezanosti i grupiranja snažniji je kada je riječ o općoj razini ekonomskog bogatstva nego kada je riječ o znanstveno-tehnološkom inoviranju. Drugim riječima, regije mogu postati inovativne makar ne bile u inovativnom okruženju, ali mnogo teže postaju bogate ukoliko nisu u bogatom okruženju. Nadalje, analiza faktora koji utječu na vjerojatnost da je neka regija bogata ili inovativna pokazuje divergenciju između tih dvaju modela uspješnosti. Za razliku od uspješnosti shvaćene kao bogatstvo, uspješnost shvaćena kao inovativnost povezana je s čimbenicima koji upućuju na liberalniji i manje egalitaran oblik razvoja. Ova je razvojna dilema od posebne važnosti za postkomunističke regije u Istočnoj Europi.

Rad je organiziran na sljedeći način: započinje se pregledom teorijske i metodološke literature koja je motivirala analizu. Zatim se eksplorativnom i vizualnom analizom predstavljaju glavni obrasci koji se naziru za europske regije. Nakon toga se predstavljaju varijable koje će biti uključene u multivarijantne prostorne modele. Potom se raspravljaju rezultati analize. Pred kraj se rad okreće razvojnim scenarijima koji se nude postkomunističkim regijama kao što su hrvatske. Završni dio rezimira i donosi zaključke.

\section{Prostor i razvoj u europskom kontekstu}

U posljednja se dva desetljeća znanstvenici iz raznih društvenih znanosti sve više okreću regionalnim aspektima razvoja. Primjerice, američki je ekonomist Paul Krugman (1991.) dobio Nobelovu nagradu za svoj doprinos "novoj ekonomskoj geografiji", formalizirajući ideju povećanih prinosa koji dovode do aglomeracije i rasta bogatih regija i njihove divergencije spram siromašnih regija. U literaturi koja je nastala u američkim poslovnim školama slične ideje promovira Michael Porter (1998.), fokusirajući se na industrijske clustere. U sociologiji je lokalne i regionalne dimenzije razvoja popularizirao Richard Florida (2002.), posebno stavljajući naglasak na važnost visokoobrazovanih pripadnika "kreativne klase". Zajedničko svim ovim doprinosima jest odmicanje od nacionalne države kao glavnog aktera razvoja i fokus na lokalne i regionalne aktere kao moguće nosioce razvojnih procesa. Ova je dimenzija od posebne važnosti u europskom kontekstu.

Europska je unija kroz strukturne fondove regije ${ }^{2}$ učinila ključnim akterima razvoja. Najveća financijska korist članstva je, nakon poljoprivredne politike, upravo regio-

\footnotetext{
2 Preciznije govoreći, ti se fondovi sastoje od strukturnih fondova i kohezijskog fonda. Strukturni fondovi su Europski fond za regionalni razvoj i Europski socijalni fond.
} 
nalna politika Europske unije. Neki analitičari smatraju kako regije mogu posebno profitirati u europskom sustavu kompleksnog višerazinskog upravljanja (Marks i Hooghe, 2001.; za raspravu kod nas vidi Nikić Čakar, 2008.). Za druge je istraživače regionalna politika Europske unije posebno zanimljiva kao pokušaj da se konvergencijom novih i starih članica uklone dispariteti u razvoju (Fingleton, 1999.; Badinger, Müller i Tondl, 2004.). Praktičan rad na problemu regionalnog razvoja u Europskoj je uniji uvelike olakšan javnom dostupnošću podataka. ${ }^{3}$

Dostupnost podataka otvara mogućnosti za kvantitativnu analizu. Pri tome valja voditi računa o tome da su prostorno organizirani podaci često obilježeni pozitivnom prostornom autokorelacijom, tj. grupiranjem jedinica s visokim vrijednostima na nekoj varijabli pored drugih jedinica $s$ visokim vrijednostima. Drugim riječima, nije moguće a priori pretpostaviti da su jedinice analize nasumično "birale" lokaciju, već se najčešće nalaze pored drugih jedinica koje su im po nekom kriteriju slične. Ukoliko se ignorira prostorni karakter podataka, klasične regresijske metode mogu dovesti do neutemeljenih uvida. U posljednja su dva desetljeća metode prostorne analize vidno napredovale pa se danas može govoriti o nekoliko dokazanih ekonometrijskih tehnika (za uvod vidi Anselin, 2010.; Voss, Curtis i Hammer, 2006.). Razvoj softvera čini prostornu analizu sve praktičnijom. ${ }^{4}$ Uz to treba dodati da je ovaj tip analize interdisciplinarnog karaktera. Sociologija, politologija ili ekonomija sve podjednako doprinose prostornoj analizi, kao što to čine i specijalizirane discipline poput geografije ili regionalne znanosti.

Polazna je motivacija ovog pristupa da jedinice analize, najčešće nepravilni poligoni poput regija, općina ili okruga, imaju s obzirom na svoju lokaciju poseban odnos s drugim jedinicama analize. Tip tog odnosa može varirati a ekonometrijskim se rječnikom dva najčešća oblika obično nazivaju prostornom zavisnošću i prostornom heterogenošću (za tehnički uvod vidi Anselin i Bera, 1998.; Anselin, 2002.; Ward i Gleditsch, 2008.). Prostorna zavisnost postoji ukoliko se nešto što se događa u jednoj jedinici nejednako prenosi na druge jedinice, najčešće tako što su bliže jedinice više izložene danom utjecaju. Formalnim rječnikom, korelacija i kovarijanca nisu nasumične, nego su utemeljene na položaju u prostoru. Prostorna heterogenost postoji ako odnos između dviju ili više varijabli važi nejednako kroz prostor, tj. važi

3 U rade se koriste podaci NUTS-II razine. Pristupljeno im je na sljedećoj internetskoj stranici (pregledano u lipnju 2012.): http://epp.eurostat.ec.europa.eu/portal/page/portal/statistics/search_database. Osnovne geografske karte koje se koriste također su javno dostupne na internetskim stranicama Eurostata (pregledano 20. lipnja 2012.): http://epp.eurostat.ec.europa.eu/ portal/page/portal/gisco_Geographical_information_maps/popups/references/administrative_units_statistical_units_1. Podaci dostupni na upit.

4 OpenGeoDa jednostavan je open-source program koji je besplatno dostupan na sljedećoj internetskoj adresi (pregledano 4. sprnja 2012.): http://geodacenter.asu.edu. Više fleksibilnosti nudi ArcGIS, koji komercijalno proizvodi ESRI (pregledano 4. srpnja 2012.): http://www. esri.com/software/arcgis/arcgis10. Statistički open-source softver R također ima brojne opcije za prostornu analizu te je besplatno dostupan na internetu (pregledano 4. srpnja 2012.): http://www.r-project.org. 
u jednom dijelu karte, ali ne u drugom. U tom slučaju korelacijski ili regresijski koeficijenti ne pokazuju stabilnost u cijelom analiziranom prostoru.

I jedan i drugi fenomen mogu biti teorijski zanimljivi, ali prostorna je zavisnost češći fenomen, te predstavlja predmet ovog rada. Analiza prostorne zavisnosti predstavlja svojevrsni proxy za neki stvarni društveni i komunikacijski proces za koji se pretpostavlja da zaista dovodi do trendova koji su uočljivi u podacima. Kao analitičko sredstvo, tehnike za istraživanje prostorne zavisnosti pretpostavljaju taj proces i pokušavaju naknadno pokazati njegove posljedice. Najprikladnija metafora bila bi širenje zarazne bolesti: blizina i daljina u tom su slučaju od očite važnosti te dovode do grupiranja.

Empirijske su aplikacije prostorne zavisnosti sada već brojne i raznolike: historijski pad i porast stanovništva (Voss, Curtis i Hammer, 2006.), rasna segregacija i nejednakost (Beggs, Villemez i Arnold, 1997.) te klasična Durkheimova tema samoubojstva (Baller i Richardson, 2002.). U analizi podataka Europske unije analitičari su već pokazali kako prostorna zavisnost igra ulogu kod ekonomskih varijabli kao što su regionalni bruto društveni proizvod i stope nezaposlenosti (Ertur, Le Gallo i Baumont, 2006.; Niebuhr 2002.). I ovaj se rad ponajprije bavi ekonomskim podacima, stavljajući fokus na ekonomsku uspješnost i faktore koji joj doprinose.

Samu se ekonomsku uspješnost može definirati na više načina. U ovom se radu odlučujem za dvije definicije: (1) ekonomski uspjeh kao opću razinu bogatstva mjerenu kroz regionalni bruto društveni proizvod po stanovniku i (2) ekonomski uspjeh kao znanstveno-tehnološko inoviranje mjereno kroz broj patenata na milijun stanovnika. ${ }^{5}$ Prva operacionalizacija predstavlja opći uspjeh neke regije i najizravnije se tiče kvalitete života. Druga operacionalizacija predstavlja uspjeh u elitnim i visoko profitabilnim privrednim sektorima i tiče se sposobnosti regije da se natječe s drugim regijama i zemljama (patenti se kao mjera uspješnosti također koriste u Hall i Soskice, 2001.). Idući dio rada započinje vizualnu i eksplorativnu analizu.

\section{Eksplorativna analiza}

Karta 1. prikazuje regionalni BDP po stanovniku, a Karta 2 broj patenata na milijun stanovnika za sve regije zemalja članica Europske unije (oba su podatka iz 2009. godine). Ukupno je 266 NUTS II regija, uključujući i tri hrvatske regije. ${ }^{6}$ Obje karte razvrstavaju regije u četiri podjednako brojne skupine, od onih s nižim vrijednosti-

5 Podaci se odnose na broj aplikacija koje su primljene u okviru Europske konvencije o patentima (European Patent Convention) ili u okviru Sporazumu o patentskoj suradnji (Patent Co-operation Treaty).

${ }^{6}$ Udaljeni teritoriji koji su službeno dio nekih zemalja članica EU, primjerice u Atlantskom i Tihom Oceanu, isključeni su iz analize. Tri hrvatske regije su Sjeverozapadna Hrvatska, Središnja i Istočna Hrvatska i Jadranska Hrvatska. Prvi podaci za te tri regije se u Eurostat bazi podataka prikazuju za 2007. godinu. 
ma koje su predstavljene svjetlijim nijansama do onih s višim vrijednostima koje su predstavljene tamnijim nijansama.

Karta 1.

Regionalni BDP po stanovniku (2009.)

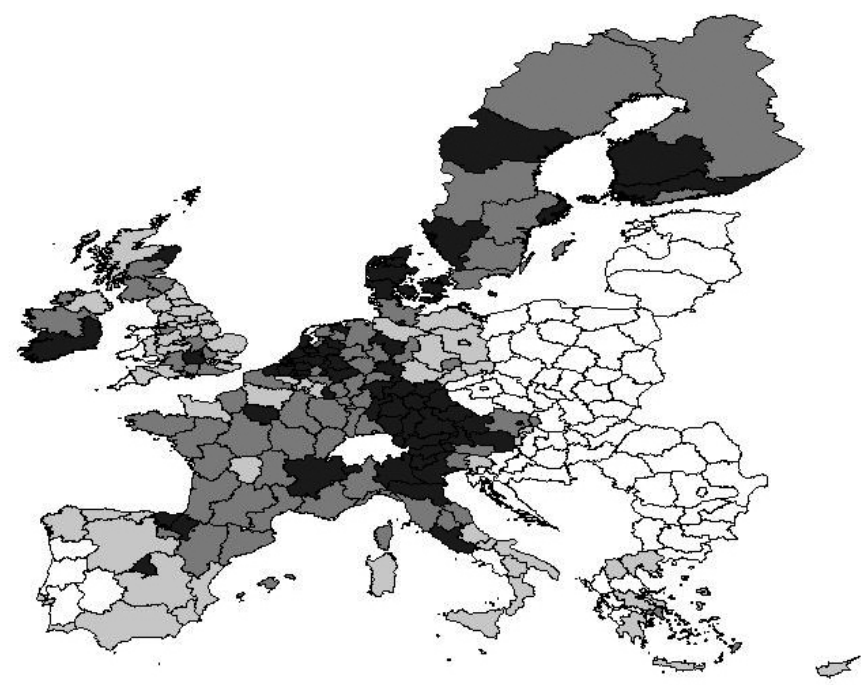

Napomena: tamnija su područja regije s većim BDP-om po glavi stanovnika.

Karta 2.

Broj patenata na milijun stanovnika (2009.)

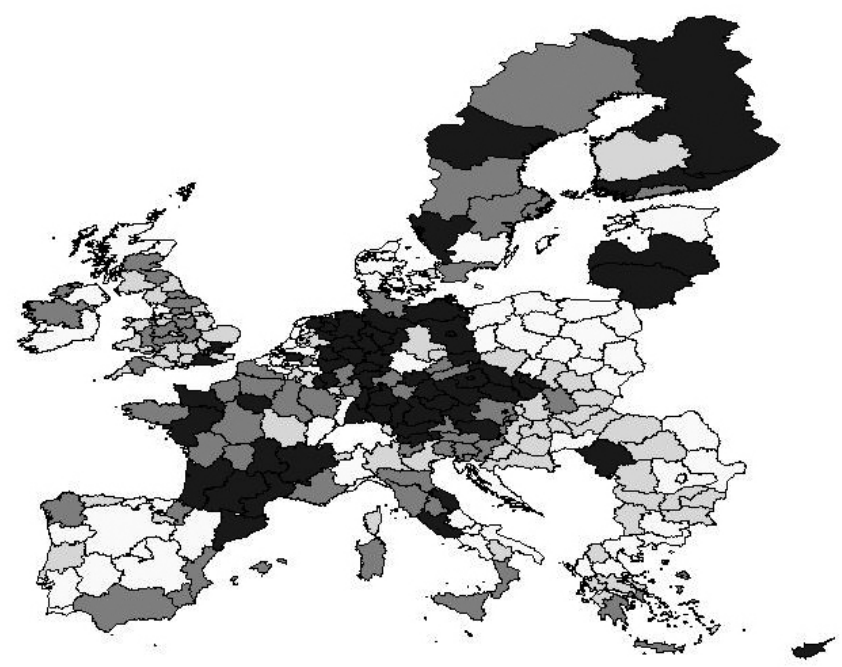

Napomena: tamnija su područja regije s većim brojem patenata na milijun stanovnika. 
Kao što se vidi iz karte 1., najsiromašnije se regije grupiraju na istoku Europe. Tu se nalaze i hrvatske regije. Najbogatije se regije grupiraju na srednjoeuropskoj osi koja uključuje jug Njemačke (Bavarsku), Austriju i sjever Italije. Bogate se regije također grupiraju na sjeverozapadu Europe (Belgija i Nizozemska) i u Skandinaviji. Srednje se bogate regije grupiraju u Francuskoj, Španjolskoj i Velikoj Britaniji. Karta 2. prikazuje broj patenata na milijun stanovnika. Na ovoj se karti nazire ponešto drugačiji raspored. Najprije treba spomenuti da neke istočnoeuropske regije sada imaju visoke vrijednosti: Latvija, Litva (čitava je zemlja jedna regija) i zapadna Rumunjska. Jug Francuske i sjever Španjolske (Katalonija) ovaj put imaju više vrijednosti nego prije, a sjever Italije i unutrašnjost Španjolske pak niže. Drugim riječima, prostorni obrasci nisu identični, te se regionalni BDP kao mjera bogatstva i patenti kao mjera uspjeha u inoviranju pokazuju kao dva različita fenomena.

Jednostavna vizualna analiza sugerira da na objema kartama postoji značajna razina grupiranja, iako je potrebno biti oprezan jer ljudsko oko traži obrasce koji objektivno možda ne postoje. Moranov I mjera je koja daje jednostavan način kako procijeniti je li fenomen prostornog grupiranja značajan. Moranov I mjeri prostornu korelaciju od -1 do 1 , po analogiji s Pearsonovim korelacijskim koeficijentom. Primjerice, šahovska ploča bila bi primjer savršene negativne prostorne korelacije (-1). Ukoliko bi sva bijela polja bila na jednoj strani, a sva crna polja na drugoj strani ploče, onda bi prostorna korelacija bila pozitivna i maksimalna (1). Za regionalni BDP Moranov $I$ iznosi 0.51 , a za patente 0.21 . To znači da je proces prostorne aglomeracije jači u slučaju BDP-a, a slabiji u slučaju broja patenata, gdje su podaci prostorno raspoređeni nešto nasumičnije. Formalno, Moranov I računa se kao:

$$
I=\frac{N}{\Sigma_{i} \Sigma_{j} w_{i j}} \frac{\Sigma_{i} \Sigma_{j} w_{i j}\left(x_{i}-\bar{x}\right)\left(x_{i}-\bar{x}\right)}{\Sigma_{i}\left(x_{i}-\bar{x}\right)^{2}}
$$

Pri tome je $N$ broj prostornih jedinica koji su indeksirani s $i$ i $j, x$ je varijabla od interesa, $\bar{x}$ je aritmetička sredina $x$, a $w_{i j}$ je element matrice prostornih utega. Moranov $I$ globalna je mjera prostorne autokorelacije, tj. predstavlja agregatni podatak za cijelu kartu. Istovremeno, metode eksplorativne analize omogućuju nam da utvrdimo status svake jedinice, što se naziva istraživanjem lokalnih indikatora prostorne asocijacije (Anselin, 1995.). Što je najzanimljivije, takva nam analiza može pokazati gdje se nalaze iznimke, one regije koje se nalaze u blizini sebi različitih regija. Kad je u pitanju regionalni BDP, takvih je iznimaka malo, što ponovno upućuje na veću važnost prostornog grupiranja. Karta 3. prikazuje iznimke kad je riječ o BDP-u. Svjetlijom su nijansom prikazane regije koje su iznimno bogate u odnosu na svoje okruženje, a tamnijom nijansom regije koje su iznimno siromašne u odnosu na svoje susjede. Jedina regija koja je iznimno bogata u odnosu na svoje susjede donja je Austrija jer je okružena bivšim komunističkim regijama. Postoji nekoliko primjera obratnih slučajeva, gdje je regija iznimno siromašna u odnosu na svoje susjede: takvih se nekoliko nalazi u južnoj Belgiji, na jugoistoku Engleske i u Sjevernoj Irskoj. 
Karta 3.

Iznimke (regionalni BDP po stanovniku, 2009.)

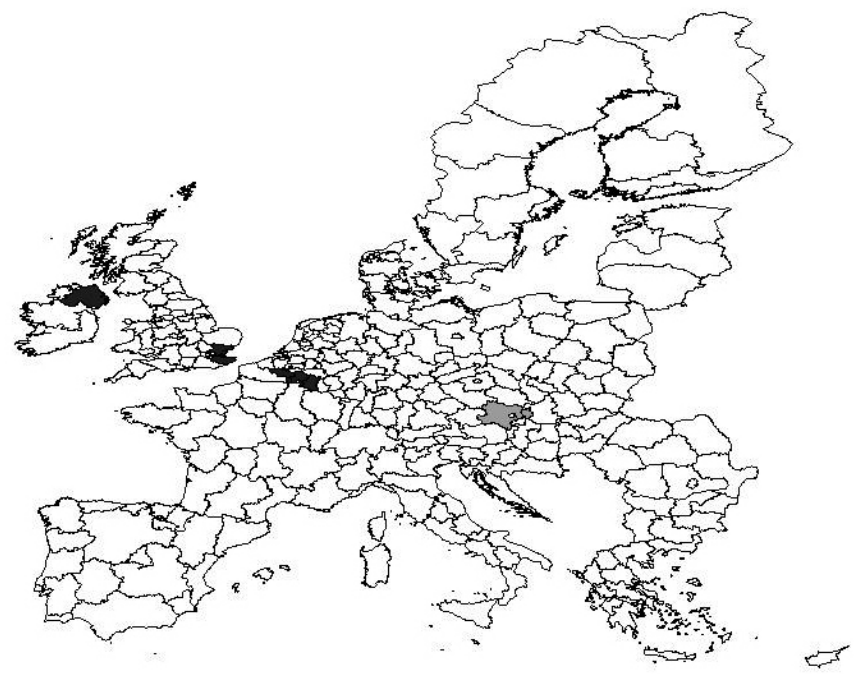

Napomena: svjetlosiva su područja pozitivne iznimke (regije koje imaju visok BDP po stanovniku u odnosu na susjedne regije), a tamnosiva su područja regije koje su negativne iznimke (regije koje imaju nizak BDP po stanovniku u odnosu na susjedne regije).

Karta 4.

Iznimke (broj patenata na milijun stanovnika, 2009.)

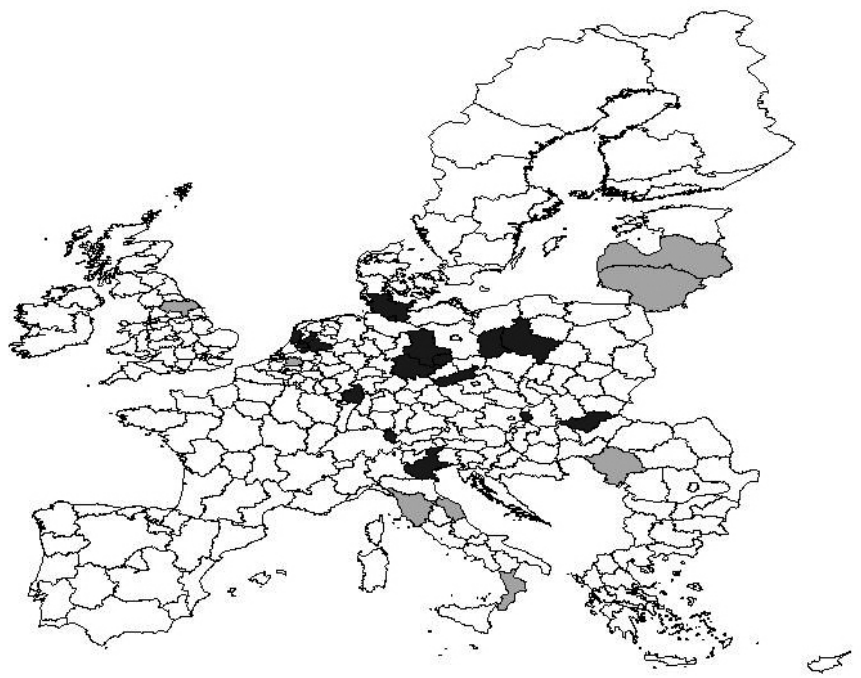

Napomena: svjetlosiva su područja pozitivne iznimke (regije koje imaju visok broj patenata na milijun stanovnika u odnosu na susjedne regije), a tamnosiva su područja regije koje su negativne iznimke (regije koje imaju nizak broj patenata na milijun stanovnika u odnosu na susjedne regije). 
Zanimljiviji su lokalni indikatori prostorne asocijacije za patente, a Karta 4. prikazuje te iznimke. Regije koje se pozitivno ističu u odnosu na svoje susjede ponovno su prikazane svjetlijom nijansom. To su prije svega Latvija, Litva i zapadna Rumunjska u Istočnoj Europi i nekoliko regija u srednjoj i južnoj Italiji. Negativne su iznimke, koje podbacuju u odnosu na susjede, prije svega nekoliko regija u Nizozemskoj i nekoliko regija u bivšoj Istočnoj Njemačkoj. Iz hrvatske i šire postkomunističke perspektive posebno je zanimljiv nalaz da se lakše otrgnuti susjedstvu kada su u pitanju znanstveno-tehnološke inovacije nego kada je riječ o općoj razini blagostanja. Međutim važnost prostorne povezanosti potrebno je ispitati i u multivarijantnom kontekstu, istovremeno ispitujući utjecaj niza faktora. Sljedeći dio rada bavi se takvom analizom.

\section{Varijable za modele prostorne zavisnosti}

Osnovna modifikacija koju prostorni regresijski modeli čine u odnosu na klasične regresijske modele je da s desne strane jednadžbe dodaju vrijednosti koje susjedne jedinice imaju na zavisnoj varijabli. Matrica utega odlučuje koje će se jedinice (i u kojoj mjeri) smatrati susjednima te biti uključene u procjenu zavisne varijable (za jednostavan uvod u ove modele vidi Anselin, 2002.). Matrica utega može biti utemeljena na udaljenosti ili na jednostavnom binarnom određivanju susjeda. Binarno određivanje susjeda i samo može varirati, ovisno o tome uključuje li se samo neposredne susjede ili se dodaje i sljedećih nekoliko koncentričnih krugova oko dane jedinice. U analizi koja slijedi koristi se matrica koja u susjede ubraja dva koncentrična kruga, ali su rezultati vrlo slični kada se uključe samo neposredni susjedi. Ostatak modela prati uobičajenu praksu regresijskih modela i uključuje vektor drugih nezavisnih varijabli.

Za svaku od dviju zavisnih varijabli, regionalni BDP po stanovniku i broj patenata na milijun stanovnika, model uključuje i vrijednosti koje susjedne regije imaju za danu varijablu. Na taj se način može istražiti koliko je važno susjedstvo: je li veća vjerojatnost da regija bude bogata ako je okružena bogatim regijama te je li veća vjerojatnost da regija bude inovativna ako je okružena inovativnim regijama. S obzirom da se istovremeno ispituje utjecaj niza drugih varijabli, ovi modeli predstavljaju stroži test teze o prostornoj povezanosti i grupiranju. Formalno, modeli prostorne zavisnosti izražavaju se kao:

$$
y=\rho w_{y}+x \beta+\epsilon
$$

Pri tome je $y$ vektor vrijednosti zavisne varijable, $w_{y}$ je vektor pomaknutih (lagged) vrijednosti zavisne varijable koristeći matircu prostornih utega $w, \rho$ je koeficijent prostorne autoregresije, $x$ je matrica nezavisnih varijabli s parametrom $\beta$ te pogreškama $\varepsilon$. Ukoliko prostorna zavisnost ne postoji i pojedini $y$ ne ovisi o susjednim vrijednostima $y$, prostorni će koeficijent $\rho$ biti jednak nuli. 
U kontekstu Europske unije postoji niz drugih varijabli koje mogu biti značajni faktori u predviđanju ekonomske uspješnosti regija. Varijable koje su uključene u ovu analizu variraju od historijskih do strukturnih, od nacionalnih do regionalnih. Najprije, veliko proširenje iz 2004. godine priključilo je Europskoj uniji većinu postkomunističke Istočne Europe. Zbog velikih razlika između Istoka i Zapada potrebno je ispitati utjecaj pripadnosti bivšem komunističkom bloku. Ova je varijabla jednostavna binarna varijabla, 1 za postkomunističke zemlje (uključujući i Hrvatsku) i 0 za ostale. Ispitujući utjecaj komunističkog naslijeđa može se dobiti odgovor na pitanje u kojoj mjeri povijesna naslijeđa određuju razvojne šanse zemalja i regija (Ekiert i Hanson, 2003.).

Slična se varijabla tiče dužine članstva u Europskoj uniji. Naime zemlje koje su duže vrijeme članice mogle su dostići veću razinu ekonomske uspješnosti. Ova varijabla varira od šest desetljeća za šest originalnih članica Europske zajednice za ugljen i čelik, do nule za tri hrvatske regije. Dužina članstva testira u kojoj mjeri vrijeme provedeno u Europskoj uniji omogućava konvergenciju regija i zemalja ka istoj razini ekonomske razvijenosti. Time se posredno ispituje i uspješnost strukturnih i kohezijskih fondova cilj kojih je dovesti do uklanjanja regionalnih dispariteta (Fingleton, 1999.; Badinger, Müller i Tondl, 2004.).

Sljedeća varijabla koju treba uključiti jest razina urbaniziranosti regije. Naime može se pretpostaviti kako ce jače urbanizirane regije biti ekonomski uspješnije. Kao mjeru urbaniziranosti koristim gustoću naseljenosti. Važnost je urbaniziranosti u širim teorijskim okvirima povezana, prije svega, s teorijom modernizacije i klasičnim sociološkim autorima sredine dvadesetog stoljeća kao što su Talcott Parsons (1960.) i Seymour Martin Lipset (1969.). Ukoliko urbaniziranost nije važan faktor u predviđanju ekonomske uspješnosti, onda se otvara prostor nekonvencionalnim razvojnim strategijama koje ne bi slijedile teleološku logiku modernizacijskih teorija i njihovu uniformnu putanju razvoja kroz urbanizaciju i industrijalizaciju.

Obrazovna struktura regije također može biti važna. Koristim dvije varijable koje mjere obrazovnu strukturu odrasle populacije: sekundarno obrazovanje koje uključuje strukovno obrazovanje i razne vansveučilišne diplome (otprilike ekvivalent više stručne spreme) i tercijarno obrazovanje koje uključuje sveučilišne diplome (otprilike ekvivalent visoke stručne spreme). Važnost ciljanog i strukovnog obrazovanja posebno je naglašena u literaturi o komparativnom kapitalizmu (Hall i Soskice, 2001.). Ovaj se tip obrazovanja smatra važnim za inkrementalno inoviranje u manje dinamičnim industrijskim sektorima. S druge strane, važnost sveučilišnog obrazovanja naglašena je posebno u literaturi o "kreativnoj klasi" (Florida, 2002.). S obzirom da je obrazovna politika jedna od mogućih razvojnih poluga, potrebno je istražiti koji su razvojni ishodi povezani s kojom obrazovnom strukturom.

Stanje na tržištu rada također je važna dimenzija. Osim što je osnova za ekonomsku aktivnost šire gledano, struktura tržišta rada mnogo nam govori o tipu kapitalizma (Esping-Andersen, 1990.). Pri tome poseban fokus stavljam na stopu zaposlenosti žena i na stopu zaposlenosti uz djelomično radno vrijeme. Jedna od glavnih prepo- 
ruka, kad je riječ o politici zapošljavanja, jest povećati udio žena u radno aktivnom stanovništvu (vidi, primjerice, Kenworthy, 2008.). Može se pretpostaviti kako će viša razina ekonomske aktivnosti žena dovesti do povećane razine ekonomskog blagostanja uopće. S druge strane, porast netipičnih oblika radnog odnosa, kao što je rad na nepuno radno vrijeme, govori mnogo o tome je li tržište rada liberalnije, tj. "fleksibilnije" ili više regulirano, tj. "rigidnije" (primjerice Esping-Andersen i Regini, 2000.).

Također uključujem i stopu zaposlenosti kao pokazatelj ekonomskih teškoća neke regije da u privredne tokove uključi najveći dio svog radno aktivnog stanovništva. $\mathrm{Na}$ ovaj se način može ispitati s kojim je razvojnim ishodima povezana povećana nejednakost, operacionalizirana kroz stopu nezaposlenosti. Sljedeći dio predstavlja rezultate multivarijantne analize koja koristi regresijske modele prostorne zavisnosti.

\section{Rezultati}

Rezultati su prikazani u tablici $1 .^{7}$ U prvom je modelu zavisna varijabla BDP po stanovniku, a u drugom modelu broj patenata na milijun stanovnika. Prve dvije nezavisne varijable prostorne su inačice zavisne varijable, tj. vrijednosti koje susjedne regije imaju na zavisnoj varijabli. U modelu za BDP prostorna je varijabla statistički značajna, a u modelu za patente nije. To pokazuje da prostorno grupiranje igra veću ulogu kod BDP-a nego kod patenata. Pri dnu je tablice i rezultat dijagnostičkog testa za prostornu zavisnost koji daje statistički značajan rezultat u prvom modelu, ali ne u drugom. Ovo se podudara s eksplorativnom analizom koja je također sugerirala kako je prostorna aglomeracija značajniji fenomen kod regionalnog BDP-a nego kod patenata.

Sljedeće su varijable patenti u modelu za BDP i obratno. Varijabla za patente statistički je značajna u modelu za BDP, dok je varijabla za BDP blizu praga statističkog značaja u modelu za patente $(p=0.054)$. Prema tome ove se dvije varijable preklapaju. Bilo bi neobično očekivati negativan odnos između bogatstva i inovativnosti. Međutim isto tako treba napomenuti da regije koje imaju najveći broj patenata na milijun stanovnika nisu u drugoj polovici distribucije po bogatstvu nego su ili u prvoj polovici ili pri aritmetičkoj sredini regionalnog BDP-a. Dakle najinovativnije regije nisu ujedno i najbogatije i obratno, najbogatije nisu ujedno i najinovatvnije.

Varijabla za komunističko naslijeđe statistički je značajna i negativna u prvom modelu (za BDP), ali ne u drugom (za patente). Dakle ako je neka zemlja postkomunistička, povećava se vjerojatnost da će biti siromašna. Ovo je očekivan rezultat s obzirom na velike razlike u ekonomskoj razvijenosti između istoka i zapada Europske unije. Međutim komunizam sam po sebi nije prepreka zemljama da postanu inovativne: varijabla je negativna, ali nije statistički značajna u drugom modelu. Drugim riječima,

\footnotetext{
7 Sve varijable odnose se na podatke iz 2009. godine.
} 
komunističku prošlost nije lako prevladati kada je u pitanju opća razina bogatstva, ali ju je nešto lakše prevladati kada je u pitanju znanstveno-tehnološko inoviranje.

Tablica 1.

Modeli prostorne zavisnosti

\begin{tabular}{|c|c|c|}
\hline & (1) & (2) \\
\hline & BDP (po stanovniku) & $\begin{array}{c}\text { Broj patenata (na milijun sta- } \\
\text { novnika) }\end{array}$ \\
\hline Prostorna varijabla (BDP) & $\begin{array}{l}0.112^{*} \\
(0.054)\end{array}$ & \\
\hline Prostorna varijabla (Patenti) & & $\begin{array}{c}0.095 \\
(0.098)\end{array}$ \\
\hline BDP & & $\begin{array}{c}0.0008 \\
(0.0004)\end{array}$ \\
\hline Patenti & $\begin{array}{l}18.143^{*} \\
(8.173)\end{array}$ & \\
\hline Komunistička zemlja & $\begin{array}{c}-11947.850^{* * * *} \\
(1640.664)\end{array}$ & $\begin{array}{l}-18.744 \\
(13.076)\end{array}$ \\
\hline Godine u EU & $\begin{array}{l}30.203 \\
(24.408)\end{array}$ & $\begin{array}{c}0.100 \\
(0.181)\end{array}$ \\
\hline $\begin{array}{c}\text { Obrazovanje } 1 \\
\text { (sekundarno nesveučilišno) }\end{array}$ & $\begin{array}{c}66.120 \\
(49.381)\end{array}$ & $\begin{array}{l}1.652^{* * * *} \\
(0.366)\end{array}$ \\
\hline $\begin{array}{l}\text { Obrazovanje } 2 \\
\text { (sveučilišno) }\end{array}$ & $\begin{array}{l}254.078^{* * * *} \\
(64.351)\end{array}$ & $\begin{array}{l}-0.644 \\
(0.484)\end{array}$ \\
\hline Stopa zaposlenosti žena & $\begin{array}{l}159.580 \\
(70.704)\end{array}$ & $\begin{array}{c}0.423 \\
(0.522)\end{array}$ \\
\hline $\begin{array}{l}\text { Stopa zaposlenosti na djelomič- } \\
\text { no radno vrijeme }\end{array}$ & $\begin{array}{l}-0.094 \\
(3.027)\end{array}$ & $\begin{array}{l}0.068^{* *} \\
(0.021)\end{array}$ \\
\hline Stopa nezaposlenosti & $\begin{array}{l}-296.725^{*} \\
(133.1709) \\
\end{array}$ & $\begin{array}{c}1.859 \\
(0.990)\end{array}$ \\
\hline Konstanta & $\begin{array}{c}3295.931 \\
(4432.712)\end{array}$ & $\begin{array}{l}-97.060^{* * *} \\
(32.717)\end{array}$ \\
\hline $\begin{array}{l}\text { Dijagnostički test za prostornu } \\
\text { zavisnost (p vrijednost) }\end{array}$ & $0.033^{*}$ & 0.345 \\
\hline Broj obzervacija & 266 & 266 \\
\hline
\end{tabular}

Napomena: Beta koeficijenti i standardne pogreške u zagradama. Statistički značajni rezultati: *** $\mathrm{p}<0.001$, *** $\mathrm{p}<0.01, * \mathrm{p}<0.05$.

Nadalje, varijabla za godine članstva u Europskoj uniji nije statistički značajna ni u jednom ni u drugom modelu. Prema tome sama duljina članstva ne donosi nužno ni povećanje BDP-a ni porast znanstveno-tehnološkog inoviranja. Iako bi za puni test isplativosti konvergencijskih politika EU trebalo promatrati podatke iz različitih vremenskih razdoblja, ovaj posredni test pokazuje ograničenost europskih napora u izjednačavanju razine ekonomske razvijenosti u Europskoj uniji. To je ponajprije 
zbog trajno nižih razina ekonomskog blagostanja na europskom jugu, prije svega Italiji, a zatim u Grčkoj i Portugalu.

Gustoća naseljenosti služi kao mjera za urbaniziranost. Varijabla je statistički značajna u prvom modelu (za BDP), ali ne u drugom (za patente). Dakle veća urbaniziranost povezana je s većom razinom BDP-a, ali je veza između urbaniziranosti i patenata puno slabija. Prema tome urbaniziranost nije preduvjet za uspjeh u znanstveno-tehnološkom inoviranju, barem ne na način na koji to jest kad je riječ o uspjehu pri dostizanju visoke razine općeg blagostanja. Kada se govori o teoriji modernizacije i njenoj predviđanoj putanji koja urbaniziranost vidi kao nužnu fazu razvoja, treba napomenuti da je to ovom analizom samo djelomično potvrđeno. Visoko inovativne regije ne moraju biti visoko urbanizirane, najvjerojatnije zbog prirode suvremene tehnologije koja omogućava "preskakanje" prostora.

Sljedeće dvije varijable testiraju važnost obrazovne strukture. Prva varijabla za obrazovanje mjeri postotak odrasle populacije koji ima sekundarno obrazovanje (strukovno i ciljano obrazovanje van sveučilišta), a druga varijabla za obrazovanje mjeri postotak populacije koji ima tercijarno (sveučilišno) obrazovanje. Prva je varijabla statistički značajna u drugom modelu (za patente), a druga u prvom modelu (za BDP). To znači da je sveučilišno obrazovanje važnije za opću razinu blagostanja, dok je ciljano i strukovno obrazovanje važnije kada je riječ o uspjehu u znanstvenotehnološkom inoviranju. Ovaj je rezultat intuitivan, ali se ne podudara s literaturom o komparativnom kapitalizmu (Hall i Soskice, 2001.). Prema toj literaturi dvije bi varijable trebale zamijeniti mjesta: sveučilišno bi obrazovanje trebalo biti važno pri objašnjavanju znanstveno-tehnološkog uspjeha, a strukovno pri objašnjavanju opće razine bogatstva.

Pri tome valja napomenuti da je ovaj tip analize ponešto ograničen u pokazivanju izravnih veza. S obzirom da se koriste agregatni podaci za regije, oni nam ne mogu reći koji se pojedinci nalaze na kojim radnim mjestima. Za puni odgovor na pitanje kakvo je obrazovanje potrebno za koji tip ekonomskog uspjeha bilo bi potrebno provesti analizu na nižoj, tj. mikro razini. Osim toga literatura o komparativnom kapitalizmu razlikuje različite vrste patenata, što s obzirom na dostupne podatke u ovoj analizi nije bilo moguće. I najzad, agregatni podaci za sveučilišno obrazovanje ne govore nam ništa o tome je li riječ o diplomama s područja društvenih ili prirodnih znanosti. Potpunija analiza veze između obrazovanja i regionalnog ekonomskog uspjeha trebala bi imati uvid u ove dimenzije problema.

Stopa zaposlenosti žena nije statistički značajna ni u jednom ni u drugom modelu. Međutim stopa zaposlenosti na djelomično radno vrijeme statistički je značajna i pozitivna u drugom modelu (za patente). Prema tome "fleksibilnije" tržište rada kompatibilnije je s inovativnom regijom nego s bogatom regijom. S ovim se rezultatom podudara i rezultat za stopu nezaposlenosti. Ova je varijabla negativna i statistički značajna u modelu za BDP, a pozitivna i vrlo blizu praga statističkog značaja u modelu za patente $(p=0.06)$. Prema tome visoka stopa nezaposlenosti nije kompatibilna s visokim BDP-om, ali je kompatibilna s uspjehom u znanstveno-tehnološkom inoviranju. Drugim riječima, za razliku od regija koje su "samo" bogate, regije 
koje su "samo" inovativne prije će biti područja u kojima uspješni sektor visokih tehnologija koegzistira s lokalnom privredom koja je obilježena visokim stopama nezaposlenosti. To vodi bifurkaciji u privrednoj strukturi inovativnih regija, pri čemu vrlo uspješan tehnološki sektor vodi život odvojen od (relativno) neuspješne lokalne privrede. Sljedeći se dio rada posvećuje ovoj dilemi s posebnim naglaskom na razvojne mogućnosti postkomunističkih regija.

\section{Razvojne mogućnosti}

Kakve razvojne scenarije otvara ova analiza? Kako bi neka regija postala bogata, od velike je pomoći ako su joj susjedi bogati. Za postkomunističke zemlje Istočne Europe ovo predstavlja veliku prepreku jer je većina regija okružena podjednako siromašnim postkomunističkim regijama. Čak i povoljno smještene češke i slovenske regije, koje su u blizini njemačkih i austrijskih regija, nisu uspjele iskoristiti efekt susjedstva za punu konvergenciju, premda jesu bogatije od ostalih postkomunističkih regija. Prosječni je BDP po glavi stanovnika za slovenske i češke regije oko 14 tisuća eura (svi su podaci za 2009. godinu), dok je za ostale istočnoeuropske regije oko 10 tisuća (ili 8 ako se isključe istočnonjemačke regije koje su nakon ujedinjenja sa Zapadnom Njemačkom bile u nešto povoljnijem položaju). S druge strane, zapadnoeuropske regije imaju prosječni regionalni BDP od više od 26 tisuća eura po glavi stanovnika. Prema tome samo se neke istočnoeuropske regije mogu pokušati razviti priključivanjem na grupaciju bogatih regija, a čak i za njih rezultati nisu sjajni.

Dok su razlike u ekonomskom bogatstvu u Istočnoj Europi male jer su sve regije na podjednako niskoj razini, razlike su u znanstveno-tehnološkom inoviranju značajnije. Najuspješnije se regije po tom kriteriju nalaze u Češkoj, gdje nekoliko regija po broju patenata nadvisuje zapadnoeuropski prosjek. Pri tome je zanimljivo napomenuti da to nisu regije na zapadu Češke već na istoku, dakle regije koje su udaljenije od zapadnoeuropskih regija. Nakon čeških visoko su inovativne regije koje su već spomenute pri eksplorativnoj analizi: zapadna Rumunjska, koja je iznimka u odnosu na ostale rumunjske regije, Litva i Latvija. Dvije slovenske regije, premda su među najbogatijim u Istočnoj Europi, ne ističu se posebno po broju patenata.

Ovdje je evidentno kako regije mogu slijediti razvojni model utemeljen na pokušajima dostizanja znanstveno-tehnološke inovativnosti bez obzira na to gdje se nalaze. Suvremena tehnologija omogućuje taj tip "preskakanja" prostora. Primjerice, istočnoeuropske regije s najviše patenata, kao što su moravskošleska regija (najistočnija češka regija), zapadnorumunjska regija, Litva i Latvija sve su regije koje su okružene isključivo drugim postkomunističkim regijama (ovdje se ostavljaju po strani istočnonjemačke regije). Prema tome inovativno susjedstvo nije preduvjet za inovativnost regija.

S druge strane, istočnoeuropske regije s najviše patenata su istovremeno regije u kojima je nezaposlenost visoka. K tome nezaposlenost u tim regijama pokazuje znakove velike volatilnosti, što je pokazatelj da je tržište rada fleksibilno i brzo reagira na ekonomsku krizu, kao što je bila ona koja je 2009. godine pogodila Europu. Pri 
tome se najekstremnija volatilnost vidi u baltičkim regijama. U Litvi je nezaposlenost skočila sa 6 posto 2008. godine na 14 posto 2009. godine, a u Latviji s 8 posto 2008. godine na 17 posto 2009. godine. Pri tome valja spomenuti da su zapadnoeuropski prosjeci bili oko 7 posto 2008. godine i oko 9 posto 2009. godine. Među najstabilnijim istočnoeuropskim regijama slovenske su regije gdje je nezaposlenost skočila s 5 posto na 7 posto (Istočna Slovenija) i s 3 posto na 5 posto (Zapadna Slovenija). Nakon Slovenije najstabilnije stope nezaposlenosti imaju poljske regije, koje su među najmanje inovativnima u Europi.

Prema tome se čini da su regije u razvoju, a među njima postkomunističke regije pogotovo, suočene s razvojnom dilemom. Ekonomski je uspjeh teško postići bez direktnog priključka na grupaciju bogatih regija. Ono što preostaje vrlo je spor i neizvjestan proces konvergencije. S druge se strane čini kako strategija traženja uspjeha u elitnim ekonomskim sektorima može polučiti uspjeh, ali dolazi u paketu s volatilnom i ekonomski neegalitarnom strukturom lokalne privrede. Na ovu dilemu hrvatske regije još nisu odgovorile. Tri su hrvatske regije, kad je riječ o BDP-u po glavi stanovnika, otprilike na istočnoeuropskom prosjeku. Pri tome Središnja i Istočna Hrvatska je najsiromašnija, a Sjeverozapadna Hrvatska najbogatija od triju regija. Kad je riječ o broju patenata, hrvatske su regije nešto ispod istočnoeuropskog prosjeka. Valja napomenuti kako Jadranska Hrvatska ima izuzetno nizak broj patenata, vjerojatno zbog oslanjanja na turistički sektor, dok druge dvije imaju podjednaki i umjereno nizak broj patenata. Prema tome dvije sjevernije hrvatske regije još se nisu posvetile ni jednoj ni drugoj razvojnoj stazi, dok je za Jadransku Hrvatsku strategija traženja uspjeha u znanstveno-tehnološkim inovacijama vjerojatno isključena.

\section{Zaključci}

Ovaj je rad analizirao faktore koji vode uspješnom regionalnom razvoju. U europskom je kontekstu na ovo pitanje moguće odgovoriti analizom podataka za regije Europske unije. Regionalni je aspekt u Europskoj uniji postao posebno važan zbog značaja fondova za regionalni razvoj, a sami su regionalni podaci javno dostupni i kvalitetni. Primjenom prostornih metoda analize u ovom se radu pokušala procijeniti važnost prostornog grupiranja i prostorne povezanosti. Prostorni se aspekt pokazao važnim, ali njegova važnost ovisi o tome kako se definira ekonomska uspješnost. Uspjeh u dostizanju opće razine ekonomskog bogatstva ima snažnu prostornu dimenziju: veća je vjerojatnost da je neka regija bogata ukoliko je okružena drugim bogatim regijama. Prostorni aspekt je slabiji kada je riječ o uspjehu u znanstvenotehnološkom inoviranju: neka regija može postati inovativna čak i kada joj susjedstvo nije inovativno.

Multivarijantni modeli utemeljeni na ideji prostorne zavisnosti potvrđuju ovaj nalaz i proširuju analizu na druge faktore koji su povezani s ekonomskim bogatstvom i inoviranjem u znanstveno-tehnološkim patentima. Za razliku od uspješnosti shvaćene kao bogatstvo, uspješnost shvaćena kao inovativnost povezana je s faktorima koji upućuju na liberalniji i manje egalitaran oblik razvoja. Tu se prije svega ističe viša nezaposlenost. Drugim riječima, regije se suočavaju s razvojnom dilemom: bez na- 
slanjanja na grupaciju bogatih regija, proces konvergencije će biti spor i neizvjestan. S druge strane, aktivno nastupanje u elitnijim znanstveno-tehnološkim sektorima može dati uspjeha bez obzira na lokaciju, ali dolazi u paketu s višim i volatilnim stopama nezaposlenosti. To sugerira odvojenost elitnog znanstveno-tehnološkog sektora od ostatka lokalne i regionalne privrede. Ova je dilema od posebne važnosti za postkomunističke regije kao što su hrvatske.

\section{Literatura}

1. Anselin, L. and Bera, A. (1998). Spatial dependence in linear regression models with an introduction to spatial econometrics, in: Ullah, A. and Giles, D. (Eds.). Handbook of Applied Economic Statistics. New York: Marcel Dekker.

2. Anselin, L. (1995). Local indicators of spatial association - LISA. Geographical Analysis, 27 (2): 93-115.

3. Anselin, L. (2002). Under the hood: Issues in the specification and interpretation of spatial regression models. Agricultural Economics, 27 (3): 247-267.

4. Anselin, L. (2010). Thirty years of spatial econometrics. Papers in Regional Science, 89 (1): 3-25.

5. Badinger, H.; Werner, M. and Tondl G. (2004). Regional convergence in the European Union, 1985 - 1999: A spatial dynamic panel analysis. Regional Studies, 38 (3): 241-253.

6. Baller, R. and Richardson K. (2002). Social integration, imitation, and the geographic patterning of suicide. American Sociological Review, 67 (6): 873-888.

7. Beggs, J.; Villemez, W. and Arnold R. (1997). Black population concentration and black-white inequality: expanding the consideration of place and space effects. Social Forces 76 (1): 65-91.

8. Ekiert, G. and Hanson, S. (Eds.). (2003). Capitalism and Democracy in Central and Eastern Europe: Assessing the Legacy of Communist Rule. Cambridge: Cambridge University Press.

9. Ertur, C.; Le Gallo, J. and Baumont, C. (2006). The European regional convergence process, 1980-1995: Do spatial regimes and spatial dependence matter?. International Regional Science Review, 29 (1): 3-34.

10. Esping-Andersen, G. and Regini M. (Eds.). (2000). Why Deregulate Labour Markets? Oxford and New York: Oxford University Press.

11. Esping-Andersen, G. (1990). The Three Worlds of Welfare Capitalism. Princeton: Princeton University Press.

12. Fingleton, B. (1999). Estimates of time to economic convergence: An analysis of regions of the European Union. International Regional Science Review, 22 (1): 5-34

13. Florida, R. (2002). The Rise of the Creative Class and how it's Transforming Work, Leisure, Community and Everyday Life. New York: Basic Books.

14. Hall, P. and Soskice D. (Eds.). (2001). Varieties of Capitalism: The Institutional Foundations of Comparative Advantage. Oxford: Oxford University Press.

15. Kenworthy, L. (2008). Jobs with Equality. Oxford and New York: Oxford University Press. 
16. Krugman, P. (1991). Increasing returns and economic geography. Journal of Political Economy, 99 (3): 483-499.

17. Lipset, S. (1959). Some social requisites of democracy: Economic development and political legitimacy. American Political Science Review, 53 (1): 69-105.

18. Marks, G. and Hooghe, L. (2001). Multi-level Governance and European Integration. Lanham: Rowman and Littlefield publishers.

19. Niebuhr, A. (2002). Spatial dependence of regional unemployment in the European Union. Hamburg Institute of international economics, Discussion paper series 26147. Pregledano 5. srpnja 2012. (http://purl.umn.edu/26147).

20. Nikić Čakar, D. (2008). "Europa s nekim regijama": slabosti teorije višerazinskog upravljanja u objašnjavanju strukturne politike Europske unije. Anali Hrvatskog politološkog društva, 4 (1): 143-170.

21. Parsons, T. (1960). Structure and Process in Modern Societies. New York: Free Press.

22. Porter, M. (1998). The Competitive Advantage of Nations. New York: Free Press.

23. Voss, P.; Curtis, K. and Hammer, R. (2006). Explorations in spatial demography, in: Kandel W. and Brown D. (Eds.). Population Change and Rural Society: Demographic Research for a New Century. Dordrecht: Springer.

24. Ward, M. and Gleditsch, K. (2008). Spatial Regression Models. London: Sage. 
Marko Grdešić

Doctoral student, Department of Sociology, University of Wisconsin, Madison, WI

e-mail:grdesic@wisc.edu

\title{
Innovative or Rich Regions? Spatial Econometric Analysis of the EU Regions
}

\begin{abstract}
This article presents a spatial econometric analysis of European Union's data on regions. The main goal of the article is to investigate factors associated with regional economic success. Economic success is defined in two ways: as the general level of economic welfare and as success in scientific and technical innovation. Visual and explorative methods of spatial analysis are used, as are multivariate models of spatial dependence. Spatial clustering is more significant for economic welfare than for scientific and technical innovation. In other words, regions can become innovative even when they are not surrounded by other innovative regions, but it is much harder for them to become rich if they are not surrounded by rich regions. Multivariate analysis shows that these two models of economic success are linked with different sets of independent variables. Unlike success defined as economic well-being, success defined as innovative potential is linked to factors which suggest a more liberal and less egalitarian model of development. This developmental dilemma is of special relevance for post-communist regions in Eastern Europe.
\end{abstract}

Key words: spatial analysis, spatial dependence, the European Union, NUTS-II, regions, regional development, regional policy. 